\section{Polarography of Nuclear Reactor Materials}

\section{Fumito Nakashima}

Hitachi Research Laboratory, Hitachi Co. Ltd.

こてでは原子炣材料に関連したポーラログラ フ分析法について述べる。まず〔I〕に打いて は核燃料を除く非分裂性金属材料の分析に関し て，また〔II〕に打いては原子炉ループに打け る水の分析に関して興味あると思われる報告を とりあげて御紹介したい.

\section{〔I〕原子炬材料の分析}

原子炉材料については，いままでの物理的， 化学的性質に加えて核的性質が重要となつてい る。そして，わずかな不純物や添加元素でもそ の中性子吸收断面積の大きさが問題になる。

原子炏材料は核然料，然料希釈材，減速材， 冷却材，反射材，制御材，遮蔽材打上び構造材 などの多種にわたるが，それらは機械的強度は 勿論の乙と，耐熱性，耐食性がよく核的性質も 良好なものでなくてはならない，実際に使用さ れている金属材料はこれらの条件を十分とはい えないまでもある程度満足しているものであつ て，それらはわずか数種に限られている。すな わち，研究用原子炬の場合には，扣をにアル之 ニウム，ステンレス鋼，ベリリウム，カドミウ ムなどであり，動力炉の場合には，打をにジル コニウム，炭素鋼，ステンレス鋼，カドミウム 八フニウムなどである。乙れらの金属材料の分 析はその金属学的研究とならんで重要なもので ある。

\section{（A）痕跡元素の分析}

鉄鋼：Milner $ら^{1)}$ は矩形波ポーラログラフに より，その特長2 を生かして 鉄銅中の微量の $\mathrm{Pb}, \mathrm{Cu}, \mathrm{Sn}, \mathrm{Cr}$ を分析した。 乙の場合には, 全く分離操作を必要としなくて, 試料 $100 \mathrm{mg}$ を酸に溶解し直接ままたは適当な支持電解質を 加えてポーラログラムをとり，てれらの定量を 行なつている， $\mathrm{Cu}$ 打よび $\mathrm{Sn}$ につては， $\mathrm{Cu}$
原子炻材料のポーラログラフィー

中島史登

日立製作所，日立研究所

$: \mathrm{Fe}=1: 5000, \mathrm{Sn}: \mathrm{Fe}=1: 20,000$ という 濃度比のものについても分離するととなく直揬 定量できた。

アルミニウム : 同じく Milner ら \3 $^{3}$ 矩形波 ポーラログラフにより, リン酸を支持電解質之 してアルミニウム合金中の微量の $\mathrm{Cu}, \mathrm{Pb}, \mathrm{Zn}$ の分析を行なつている。 また，Neumann ${ }^{4)}$ 99.9 99.99\%ไいう高純度のアルミニウムを 塩酸に溶解して濃厚アルミニウム塩溶液とし, その中の微量の $\mathrm{Cu}, \mathrm{Fe}, \mathrm{Zn}$ を通常ポーラログ ラフによつて定量した。

ジルコニウム：オークリッジ国立研究所"゙ で は，スペクトルグラフ法のチェックとして $\mathrm{Zr}$ 金属に含まれる微量の $\mathrm{Fe}, \mathrm{Ti}$ の痕跡量をポー ラログラフ的に定量しようと試みている。

ベリリウム：Be は熱中性子吸收断面積が小 さく，反射材として用いられている（材料試験 炉MTR)。アルゴンヌ国立研究所の $\mathrm{Bane}^{6)}$ は Be 金属を塩酸に溶解し，直接通常ポーラログ ラフ法によつて 150 800 p.p.m. の Pb を定量 した。 同一試料について, Argonne National Laboratory, National Bureau of Standards 打よび Battelle Memorial Institute に扑いて 行なわれた化学分析, 吸光光度分析, ポーラロ グラフ分析の結果を比較して，よく一致するて とを認めている。

（B）原子炉用合金の分析

ジルカロイ : 原子力計画の発展とともに新し く工業的規模で生産されるようになつた金属の 一つにジルコニウムがある。 Zr はその核的性 質，打よび耐食性が特に優秀であるため，合金 燃料の添加元素，燃料クラッド，構造材料など に使用されている。しかし純ジルコニウムは高 温強度が少るので，種々の金属を添加して合金 を作り耐熱性と耐食性を改善しょうとしてい 
るそその中で殊に，Zr-Sn 合金であるジルカロ イ (Zircaloy) が最も優れている.

Porter $\mathrm{II}^{7)}$ はジルカロイの中の Sn をポーラ ログラフ法で定量した。試料を窒素気流中で塩 酸, 硫酸, フッ化ホウ素酸に加熱溶解して Sn し酸化を妨げる方法と，いつたん溶解してのち 鉄粉を加えて䇪素気流中で $\mathrm{Sn}^{4^{+}}$を $\mathrm{Sn}^{++}$に還 元する方法との二つの方法で武料溶液を調製し た。てれを希釈し，ペプトンを極大抑制郕とし て加えてポーラログラムをとつた。とのとき $\mathrm{Sn}^{++}$は半波電位. $\mathrm{E}_{1 / 2}=-0.48 \mathrm{~V}$ vs. S.C.E. に典型的な還元波をあた光る。乙の波高を測る ことにより約 $1.5 \% \mathrm{Sn}$ を含む三種のジルカロ イ試料について標準偏差士 $2 \%$ Sn を定量し た。またジルカロイを原子炉に応用する場合に は, ウラン共存時の $\mathrm{Sn}$ の定量が必要となるが, ジルカロイに対して7.5\%のウラン $\left(\mathrm{UO}_{2} \mathrm{SO}_{4}\right.$ として）が共存していても Sn の定量に妨害は なかつた。 ジルカロイには $\mathrm{Sn}$ の他に Fe, Ni,Cr が少量含まれているが (第 1 表), $\mathrm{Fe}^{3+}$ が共存 しないかぎり，いずれも Sn の定量に妨害はな かつた。

アイダホの化学プロセス・プラントの研究部 門8)では, $\mathrm{Sn}$ を $\mathrm{SnBr}_{4}$ の形で蒸留し, てれを 強酸性支持電解質中でクッペロンを用いて電流 滴定して定量した。 $\mathrm{Cu}, \mathrm{Fe}, \mathrm{Nb}, \mathrm{Mo}, \mathrm{Ti}, \mathrm{W}$ など は妨害とならず, $\mathrm{Zr}$ もル比にして $100: 1$ までは妨害しないから，本法は $\mathrm{Zr}$ 合金中の $\mathrm{Sn}$ の定量法として推奨されるという。

合金燃料：金属ウランは機械的強度がかなり 弱く，耐食性の点でも劣つているので，乙れを 克服するためにウラン合金を原子炬燃料として 用いる場合がある。アルゴンヌ国立研究所の沸 騰水型動力炉 EBWR に用いられている U-Zr$\mathrm{Nb}$ 合金もその一例である。

Elving 抒よび Olson'は，乙の合金燃料の分
析を目的として，合成試料を用いてポーラログ ラフ的に迅速, 簡単, 正確に分析する方法を研 究した。 U-Zr 混合物については, 10\%硫酸溶 液中でUをポーラログラフ的に定量し，一方別 の試料溶液について固定電位 -1.0 V vs. S. C. E. に打いて，クッペロンを沈殿試薬として $\mathrm{Zr}$ の電流滴定を行なつた。

$\mathrm{U}-\mathrm{Zr}-\mathrm{Nb}$ の混合物については $\mathrm{Zr}$ を, $\mathrm{H}_{2}$ $\mathrm{O}_{2}-\mathrm{H}_{2} \mathrm{SO}_{4}$ 溶液からリン酸塩として分離し, 乙 のリン酸塩の懸濁物をクッペロンによつて電流 滴定し，U扣よび $\mathrm{Nb}$ は濃塩酸中で直接ポーラ ログラフ法によつて同時定量した。 その結果, U,Nb については $1.0 \%, \mathrm{Zr}$ について $0.5 \%$ の精度で定量された。

$\mathbf{M g}-\mathbf{Z r}$ 合金 : マグネシウム合金に $\mathrm{Zr}$ を添 加すると耐熱性と機械的性質が良くなるのでシ エット・エンジン用耐熱合金として使用されて いるが，原子炉材料として使用される可能性を ある. Elving, Olson ${ }^{10}$ は $\mathrm{Zr} 0.8 \%, \mathrm{Zn} 6 \%$ を含むものと, $\mathrm{Zr} \mathrm{0.4 \% ,Zn} 3 \%$ を含むるの の二種の市販 $\mathrm{Mg}$ 合金の申の $\mathrm{Zr}$ をクッペロン を用いて電流滴定法により定量した。

\section{(C) その他}

第IV B 族元素 ( $\mathrm{Ti}, \mathrm{Zr}, \mathrm{Hf}, \mathrm{Th})$ は合金元素 として，また殊に原子炉材料として重要なもの となつてきたためその分析の興味も増してき た。乙れらの元素は水溶液中では 4 価で加水分 解を扣てし易いが，乙れを避けるためには水素 イオン濃度を大きくしなければならない。また てれらは良好なポーラログラフ波をあたえな い. Elving, Olson ${ }^{11)}$ は Ti,Zr,Hf を 10\%硫酸 溶液中でクッペロンによつて沈殿させ, 電流滴 定法によつて定量した。クッペロンは強酸性溶 液中で典型的な還元波をあたえるので, 電流滴 定にはこのクッベロンの波を利用している. Th 以外の第IVB族元素は硫酸溶液中で次式の

第 1 表 シルカロイの組成（\%)

\begin{tabular}{|c|c|c|c|c|c|}
\hline & & Sn & $\mathrm{Fe}$ & $\mathrm{Cr}$ & $\mathrm{Ni}$ \\
\hline & ルカ口 1 & 2.5 & & \multirow{3}{*}{$0.05 \sim 0.15$} & \multirow{3}{*}{$0.03 \sim 0.08$} \\
\hline : & ルカロ & $1.2 \sim 1.7$ & $0.07 \sim 0.20$ & & \\
\hline & ルカロ & $0.25 \sim 0.50$ & $0.25 \sim 0.40$ & & \\
\hline
\end{tabular}


ようにクッペロンで沈殿し，10\%硫酸中に打け る沈殿の溶解度は $10^{-7} \mathrm{M}$ 程度である。

$$
\mathrm{M}\left(\mathrm{SO}_{4}\right)_{3}{ }^{--}+4 \mathrm{Cup}^{-}=\mathrm{M}(\mathrm{Cup})_{4}+3 \mathrm{SO}_{4}^{--}
$$

ての方法の精度は $0.3 \%$ であり，妨害イオンは $\mathrm{Fe}(\mathrm{III}), \mathrm{V}(\mathrm{V}), \mathrm{Nb}(\mathrm{V}), \mathrm{U}(\mathrm{IV})$ などである.

アイダホの化学プロセス・プラントの分析化 学マニュアル ${ }^{12)}$ にると，てのクッペロンによ る Zr の電流滴定法は潜水艦用熱中性子炉 STR や実験用増殖炉 EBR-2 に打けるプロセス試 料に直接適用できるものであるという。

\section{〔ா〕 原子炉ループにおける分析}

原子炉材料に関連して，ポーラログラフ法の もう一つの応用は, 冷却材または減速材として 用いられる水や均質炉の燃料溶液の中に含まれ る腐食生成物打よび添加物の分析である。乙の 場合の水または水溶液は放射性をおびているの で，その分析には遠隔操作ができるととが必要 で，理想としては自動的に定量可能な方法が望 ましい。ポーラログラフ法をはじめとして，電 気化学的分析法は電解槽部分のみを放射線の照 射下に打けばよく，溶液の調製も比較的簡単で あるから，他の機器分析法に比べてての目的に 合つている ${ }^{13)}$.

アイダホの化学プロセス・プラントでは遠隔

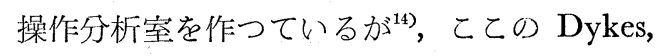

Masterson Rein ${ }^{15)}$ は遠隔操作によつて酸扣よ びアルミニウムの電位差滴定，フッ化物の電郋 度滴定，ジルコニウムの電流滴安などを試みて 良好な結果を得た。

原子炉では高温の水, 水溶液打よび液体金属 を取扱うが，乙れと接触している各種金属材料 の窝食が問題になる ${ }^{16)}$. 原子炬に扣ける简食は 強い放射線照射のもとで起るたも，通常の高温 水による腐食に比して一般にこの窝食速度が大 きい，水の中に入つた简食生成物は中性子の照 射をうけて放射化されて炕心の外へ出てくるた め厄介なもので，てれを分析するてとは単に用 いた材料の简食進行の程度を知るためのみなら ず，原子炉の運転に㧊いても重要な意味をるつ ている.

\section{(A) 燃料溶液の分析}

オークリッジ国立研究所の Horton らは，均 質炉然料である硫酸ウラニル水溶液中に含まれ る金属窗食生成物 ${ }^{17)}$ ，扣よび防食のために添加 されるクロム ${ }^{18)}$ を遠隔操作によつて，イオン交 換法とポーラログラフ法または吸光光度法とを 併用して分析した。乙の場合特に，イオン交換 カラムからの流出液をポーラログラフ法によつ て分析する方法は遠隔操作分析法として理想的 なものであり均質炉の Fuel control の目的を 満たするのである一ことを指摘している，以下

第 2 表 否食生成物打よび添加物の分離

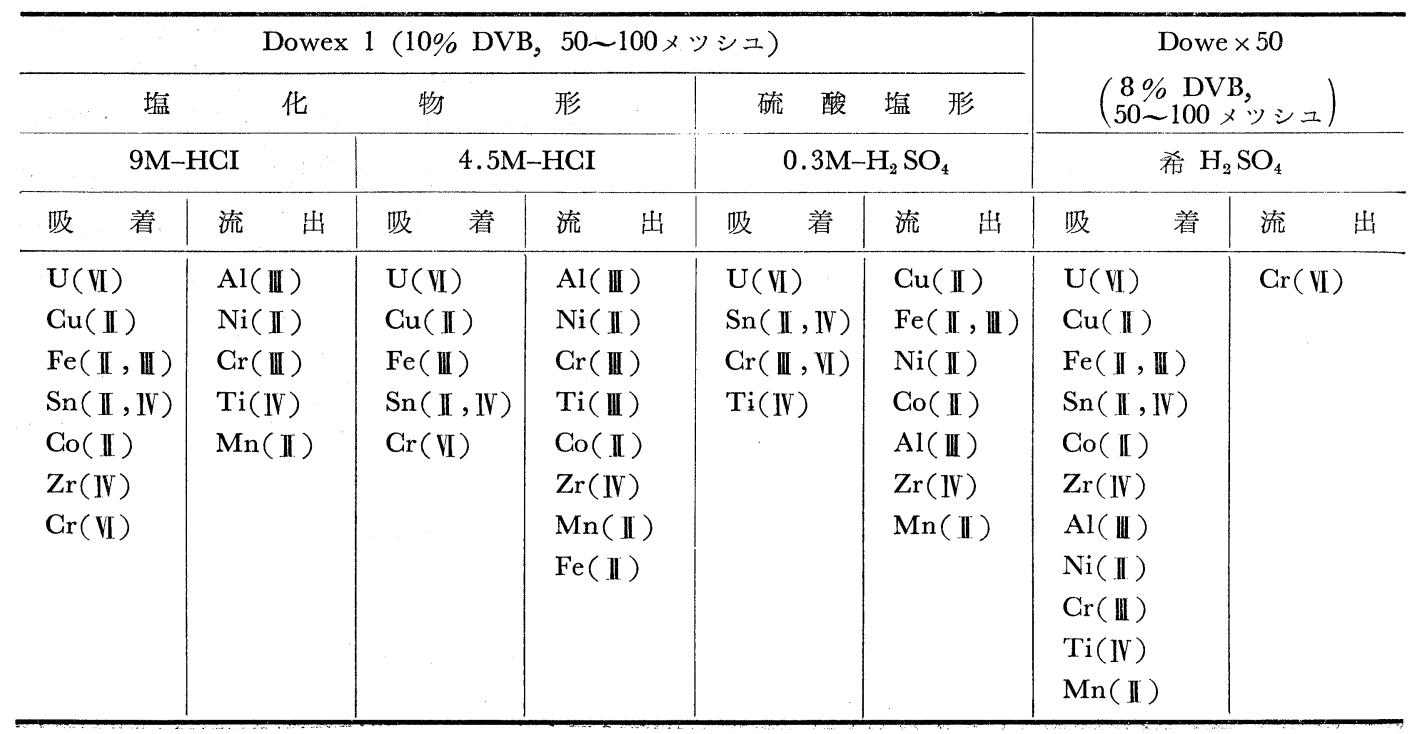


その概略を説明しょう。

均質炉の然料溶液は核然料として $\mathrm{UO}_{2} \mathrm{SO}_{4}$, 防食のために加える $\mathrm{K}_{2} \mathrm{Cr}_{2} \mathrm{O}_{7}$, 酸素と水素の再 結合反応の触媒として㗢く $\mathrm{CuSO}_{4}$ を含む硫酸 陖性水溶液である。乙れを，例えばオークリッ シ国立研究所の実験用均質炉 HRE では直径 18 インチの 347 ステンレス鋼製球状容器に入れて いる，溶液が酸性であるのと，高温 $\left(80^{\circ} \mathrm{C}\right.$ 前後 $)$ で，しかも強い放射線の照射をうけるので接触 している材料の腐食が起り笗食生成物が溶液中! に混入する. Horton ら ${ }^{17)}$ は下記のような組成 の均質炣燃料溶液を合成して分析した。

$\mathrm{U}(\mathrm{VI}), 40 ; \mathrm{Al}(\mathrm{III}), 0.05 ; \mathrm{Ni}(\mathrm{II}), 0.1$;

$\mathrm{Fe}(\mathrm{III}), 0.1 ; \mathrm{Zr}(\mathrm{IV}), 0.1 ; \mathrm{Cu}(\mathrm{II}), 0.1$;

$\mathrm{Cr}(\mathrm{III}), 0.05$ ；（単位はいずれも $\mathrm{g} /$ liter)

陰イオン交換樹脂 Dowex 1 あるいは陽 イ オン交換樹脂 Dowex 50 をつめたカラムに, 酸性度を調整した試料溶液を流すと第 2 表に示 すような分離が行なわれる。樹脂に吸着されず に流出した部尔はポーラログラフ電解槽に直接 うけいれられる。必要があれば，乙れをヒ一タ で蒸発乾固したのち，それぞれの場合に応じて 適当な支持電解質中でポーラログラムをとる。

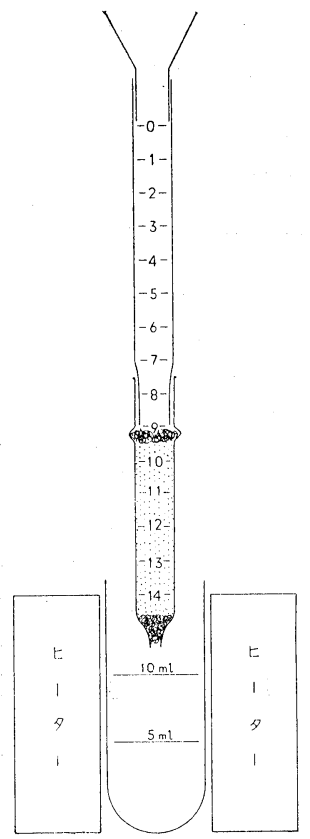

第 1 図 イオン交換樹脂カラムと電解槽 ${ }^{17}$ )
第 1 図はその原理図である。

$\mathrm{Al}$ (III) と $\mathrm{Zr}$ (IV) は吸光光度法で, 他のCo ( II), $\mathrm{Ni}($ II $), \mathrm{Cr}$ (III), $\mathrm{Fe}($ III), $\mathrm{Mn}($ II ), $\mathrm{Cn}(\mathrm{II})$ などはポーラログラフ法で定量してい 万.

$\mathrm{Al}$ (JII) : 試料液を $9 \mathrm{M}$ 塩酸酸性に調整し,

Dowex 1 を通し，流出液を蒸発乾固したのち 塩酸とピリシンを加え，アルミノン緩衝液を加 える。沸騰浴中で 5 分間加熱して後, 一定容積

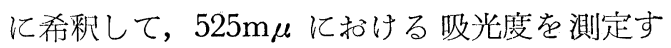
るととにより定量を行なつた。

$\mathrm{Ni}(\mathrm{II}), \mathrm{Co}$ (II) : 4 M塩酸酸性にして Dowex 1 を通し流出液をポーラログラフ電解槽に うけいれて蒸発乾固する。乙れに, $5 \mathrm{ml}$ に希 剩するとき丁度 $0.1 \mathrm{M}$ ピリシシンー $0.1 \mathrm{M}$ 塩化ピ リシン溶液になるように塩酸とピリジンとを加 える.乙の $5 \mathrm{ml}$ 溶液についてポーラログラム をとり, 头波電位. $\mathrm{E}_{1 / 2}=0.78$ Vvs. S.C.E. で $\mathrm{Ni}$ を, $\mathrm{E}_{1 / 2}=-1.07 \mathrm{~V}$ vs. S.C.E. で Co を それぞれの波高を測つて定量した。

$\operatorname{Cr}($ III ) : 過マンガン酸カリを加えて沸騰す るまで加熱し 完全に $\mathrm{Cr}(\nabla \mathrm{I})$ に酸化してから Dowex 50 に通すと他の金属陽イオンから分離 される。流出液はあらかじめ 3 個の $\mathrm{NaOH}$ 粒 を入れた電解槽にとり， $10 \mathrm{ml}$ に希勫して $\mathrm{E}_{1 / 2}$ $=-0.85$ Vvs. S.G.E. の波について定量した.

$\mathrm{Fe}$ (全鉄量)：0.3 $\mathrm{M} \mathrm{H}_{2} \mathrm{SO}_{4}$ に調整し, 希硝 酸で洗つたカドミウム箔をこれに浸け，15分間 攪抖することにより共存する銅を析出させて除 去する，次に過マンガン酸カリで鉄を再酸化 し, 硫酸塩形 Dowex 1 亿通す。流出液はクエ ン酸を支持電解質として鉄の定量に供する。 $\mathrm{E}_{1 / 2}=-1.5$ Vvs. S.C.E. の波について定量し た。

$\mathrm{Mn}$ (II ) : 試料液は $9 \mathrm{M}$ 塩酸酸性にして Dowex 1 に通し, 流出液は蒸発乾固したのち $1 \mathrm{~N}$ $\mathrm{KCN}$ 溶液 $5 \mathrm{ml}$ を加えて溶かし, $\mathrm{E}_{1 / 2}=-$ $1.33 \mathrm{~V}$ vs.S.C.E. の波の波高を測つて定量し た。

$\mathrm{Zr}(\mathrm{IV})$ ：試料液を $9 \mathrm{M}$ 塩酸酸性にして Dowex 1 に通し, 吸着した $\mathrm{Zr}(\mathrm{IV})$ は $4 \mathrm{M}$ 塩酸で 溶離する, 溶離液は蒸発乾固して後, 濃硫酸 7 
滴，20\%七ドロキシルアミン $1 \mathrm{ml}$ と $0.2 \%$ ト ロン試薬 $1 \mathrm{ml}$ を加光 $10 \mathrm{ml}$ に希釈する。乙れ について波長 $555 \mathrm{~m} \mu$ に扣ける吸光度を測定し て定量した。

$\mathrm{Cu}(\mathrm{II})$ ：イオン交換樹脂で分離せず， EDT A を加えて $\mathrm{E}_{1 / 2}=-0.55 \mathrm{~V}$ vs. S,C.E. の波 を測つて定量した。

以上の各方法によつて最低， $\mathrm{Al} ， 5$; $\mathrm{Ni} 10$; $\mathrm{Cr}, 10 ; \mathrm{Fe}, 20 ; \mathrm{Zr}, 10 ; \mathrm{Cu}, 5$; $\mathrm{Co}, 10 ; \mathrm{Mn}$, $10(\mu \mathrm{g} / \mathrm{ml})$ まで $2 \sim 3 \%$ 精度で定量してい る.

さらに Horton $ら^{\left.{ }^{18}\right)}$ は，第 2 報として Cr を 同様な方法で定量するためにイオン交換樹脂力 ラムの大きさなど詳しく研究した。均質炉燃料 は 40g/lU(VI)，2 g/l Cu(II)，打よび 0.2 $0.5 \mathrm{~g} / \mathrm{l} \mathrm{Cr}(\mathrm{VI})$ を含んでいる. $\mathrm{Cr}(\mathrm{VI})$ はステ ンレス鋼容器の窝食を妨げる目的であらかじめ 加えられているものである。しかしその大部分 は容器壁などに析出して，わずか10\%程度が溶 液中に残つているだけであり，また溶液中の $\operatorname{Cr}(\mathrm{VI})$ の一部は $\mathrm{Cr}(\mathrm{III})$ に還元されていると いう証拠もある。そこで次のような組成の合成 試料についてクロムを遠隔分析している.

\begin{tabular}{|c|c|c|c|}
\hline 試 料 & 液 & 試 料 & 液 \\
\hline U（VI） & $40 \mathrm{mg} / \mathrm{ml}$ & $U(V)$ & $40 \mathrm{mg} / \mathrm{ml}$ \\
\hline $\mathrm{Cu}(\mathbb{I})$ & 2 & $\mathrm{Cu}($ II $)$ & 2 \\
\hline Co (II) & 0.1 & Co (II) & 0.1 \\
\hline $\mathrm{Ni}(\mathbb{I})$ & 0.1 & $\mathrm{Ni}(\mathbb{I I})$ & 0.1 \\
\hline \multirow[t]{2}{*}{$\operatorname{Cr}(\mathbb{I I})$} & 0.020 & $\mathrm{Cr}($ III $)$ & 0.020 \\
\hline & & $\mathrm{Cr}(\mathrm{VI})$ & 0.020 \\
\hline
\end{tabular}

$\mathrm{Cr}$ (III) は試料液を $9 \mathrm{M}$ 塩酸酸性にして，陰 イオン交換樹脂 Dowex 1 に通すと Cr(III) は 吸着されずに流出する。流出液は蒸発乾固し， $0.1 \mathrm{M} \mathrm{NH}_{4} \mathrm{OH}-\mathrm{NH}_{4} \mathrm{Cl}$ 緩衝液を支持電解質と してポーラログラムをとると， $-1.42 \mathrm{~V}$ vs. S.C.E. に $\operatorname{Cr}($ III $) \rightarrow \operatorname{Cr}$ (II) の還元波をあたえ るが，感度は悪く $10 \mu \mathrm{g} / \mathrm{ml}$ 以上の濃度でなけ ればならない。

Cr (VI) の定量万法は前報に全く同じである. したがつて過マンガン酸カリウムによつて酸化 して全クロム酸 $(\mathrm{Cr}(\mathrm{III})+\mathrm{Cr}(\mathrm{VI}))$ を定量す
れば， $\mathrm{Cr}$ (III) を直接定量しなくてす $\mathrm{Cr}(\mathrm{III})$ は求まる。ポーラログラフに供せられる試料は イオン 交換分離ののち 希釈されてその濃度が $1 / 10$ に減少している。精度は $\operatorname{Cr}(\mathrm{VI})$ てつい ては濃度 $2 \mu \mathrm{g} / \mathrm{ml}$ で $2 \%$ ，全クロム量につい ては濃度 $4 \mu \mathrm{g} / \mathrm{ml}$ で $3 \%$ あつた。

\section{(B) 水の分析}

ハーウェルの AERE 分析化学グループの Ferrett と Milner ${ }^{19}$ は原子炉飞打ける简食生 成物を分析する目的で，矩形波ポーラログラフ の適用について研究している。

ステンレス鋼の简食生成物の主なものは鉄, クロム, マンガン, ニッケルである。乙の研究 では，試料液は $2 \mathrm{ml}$ だけで十分であり， $1 \mathrm{ml}$ は $\mathrm{Fe}$ と $\mathrm{Cr}$ の分析に, 残りの $1 \mathrm{ml} \mathrm{Mn}$ 之 $\mathrm{Ni}$ の分析に用いた。 クロムを過硫酸塩で酸化 したのち，マニトールを含む $\mathrm{NaOH}$ 溶液から

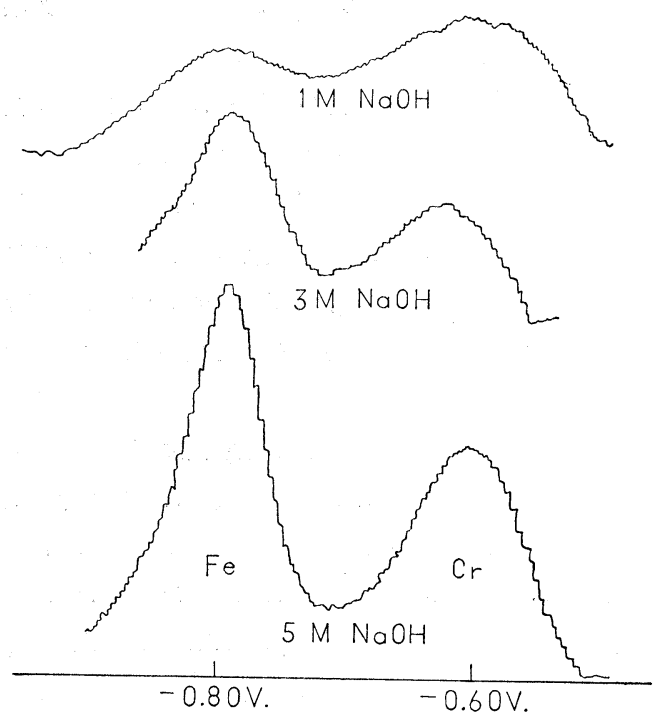

第 2 図 $\mathrm{NaOH}$ の濃度による可逆性の変化 ${ }^{19}$ $\mathrm{Fe} \sim 10 \mu .8 / \mathrm{ml}, \mathrm{Cr} \sim 6 \mu \mathrm{g} / \mathrm{ml}$, $3 \%$ ニトール

クロムと鉄のポーラログラムを記録した（第 2 図)。いろいろ検討した結果，3\%マニトール $5 \mathrm{M} \mathrm{NaOH}$ を支持電解質とすると最も良好な ことが分り，鉄打よびクロムの半波電位はそれ ぞれ $-0.8 \mathrm{~V}$ vs.Hg 電極, $-0.6 \mathrm{~V}$ vs. $\mathrm{Hg}$ 電椣であつた。この方法で润者ともに 1 p.p. m. の濃度まで同時定量でき，0.2 p.p.m.まで 
検出可能である.

ニッケルとマンガンは酸性または中性では可 逆的に還元されないから，可逆性を増すために いろいら試みられたが，結局， $1 \mathrm{M} \mathrm{NaOH，}$ $0.03 \mathrm{M} \mathrm{KCN}$ を支持電解質として定量してい る。また溶存酸素を除去するために亜硫酸り一 ダの飽和溶液を $0.1 \mathrm{ml}$ 加えた. $\mathrm{Ni}$ 打よび $\mathrm{Mn}$ は，それぞれ 0.4p.p.m. 打よび 2 p.p.m. まで 定量でき，検出限量は打の打の 0.06 p.p.m. 0.4 p.p.m. であつた。

矩形波ポーラログラフを用いる窗食生物の分 析は，分離操作が全く不要である点之，感度が 良い点で Horton らが行なつた方法より優れ ている。

\section{(C) 重水の分析}

最後に重水の中のカドミウム扎よびアルミニ ウムの分析に単掃引陰極線ポーラログラフ (linear sweep cathode ray polarograph）を適用 した例 ${ }^{200}$ を紹介しよう。

カドミウムは, 電解槽に $2.0 \mathrm{ml}$ の重水試料 を入れ， $1 \mathrm{M} \mathrm{KGl}$ を $0.05 \mathrm{ml}$ 加えて直接定量さ れた，溶液を完全に脱酸素してのち， $-0.7 \mathrm{~V}$ vs. Ag 電極に打ける Cd の波のピークを測り 標準添加法によつて定量した。検出限量は0.02 p.p.m. で，一回の定量に要する時間は 30 分で あつた。

アルミニウムの定量には, 重水試料 $5 \mathrm{ml}$ を とり, $5 \mathrm{MHClO}_{4} 0.2 \mathrm{ml}$ と $2.5 \mathrm{M}\left(\mathrm{NH}_{4}\right) \mathrm{CO}_{2} \mathrm{CH}_{3}$ $0.8 \mathrm{ml}$ ，それに $0.05 \%$ ポンタクロム・バイオレ ット SW (5-sulpho-2-hydroxy- $\alpha$-benzenazo$\beta$-naphthol) の $4 \mathrm{ml}$ を加え， $10 \mathrm{ml}$ に希釈して 5 分間 $70^{\circ} \mathrm{C}$ で加熱する. 冷却して $-0.53 \mathrm{~V}$ vs. $\mathrm{Ag}$ 電極に現れる $\mathrm{Al}$ - 色素錯化合物の 還元波 を用いて定量している. 検出限量は 0.02p.p.m. であつた。

おわりに

ポーラログラフ法は遠隔操作に適している点 では，原子炬に扣ける分析の問題に適用して優 れた性能を発揮できる分析法であるが，ての感 度の点では，原子㷋材料のみならず各種の分析 の要求に対して必ずしも満足なものではない.
原子炉材料のポーラログラフ的分析例が比色法 や放射化学的方法に比べて比較的少ないのはこ のためであると思われる，ハーウェルの AER $\mathrm{E}$ の化学打よび分析化学部門に扣いてはすでに 市販されている矩形波ポーラログラフをはじめ としてパルス・ポーラログラフ，高周波ポーラ ログラフなどと高感度のポーラログラフを開発 しようと意欲的な研究が行なわれている ${ }^{21_{222} \text {. }}$. こうした電気的増感法の他にもう一つ興味深い 方法として 陽極溶出ボルタメトリー (anodic stripping voltammetry) ${ }^{22232)}$ がある. 今後てれ らの高感度法の発展が期待される。

現在建設されている原子炉のほとんどが熱中 性子炉であるために用いられている材料はわず か数種にすぎないけれども，今後高速中性子炉 などの新しい原子炉が開発されるならば用いら れる材料も広く開拓されるであろう。そうなる とこれらの分析に光学的分析法や放射化学的分 析法などとともにポーラログラフ法も大いに活 用せられるであろう。

終りにのぞみ，種々の御指導，御助言をたまわつた 広島大学品川教授ならびに当研究所高橋部長，川島主 任研究員，酒井主任に深く感謝いたします。

文献

1) D.J. Ferrett and G.W.G. Milner, Analyst, 81, 193 (1956).

2) D.J. Ferrett, G.W.C. Milner, H.I. Shalgosky and L.J. Slee, ibid., 506 (1956).

3) G.W.G. Milner and L.J. Slee, ibid., 82, 139 (1957).

4) R. Neumann, Z. anorg. u. allgem. Chem., 279 234 (1955).

5) J.A. Stwartout et al., U.S. Atomic Energy Comm., Rep. ORNL-607 (1949).

6) R.W. Bane, Anal. Chem., 27, 1022 (1955).

7) J.T. Potter II, ibid., 30, 434 (1958).

8) C.E. Stevenson, ed., U.S. Atomic Energy Comm., Rep. IDO-14443 (1958).

9) P.J. Elving and E.C. Olson, Anal. Chem., 28, 338 (1956).

10) ibid., 28, 251 (1856)

11) ibid., 27, 1817 (1955). 
12) J.H. Sikes and J.E. Rein, U.S. Atomic Energy Comm., Rep. IDO-14316 (Suppl.3) (1957).

13) 品川, 化学々工業, 11，214 (1958).

14) F.W. Dykes, R.D. Fletcher, E.H. Turk, J.E. Rein and R.C. Shank, Anal. Chem., 28, 1084 (1956) : G.A. Huff, U.S. Atomic Energy Comm., Rep. IDO-14434 (1958).

15) F.W. Dykes, R.G. Masterson and J.E. Rein, U.S. Atomic Energy Comm., Rep. IDO-14406 (1957).

16) 伊藤，電化，25，148 (1957).

17) A.D. Horton, P.F. Thomason and M.T. Kelley, U.S. Atomic Energy Comm., Rep. ORNL -1746 (1954); Anal. Chem., 29, 388 (1957).

18) A.D. Horton and P.F. Thomason, U.S. Atomic Energy Comm., Rep. ORNL-1887 (1955).

19) D.J. Ferrett and G.W.C. Milner, Proceedings of the International Conference on tne Peaceful Uses of Atomic Energy, Geneva 1955, P/
412, Vol.9, United Nations, NewYork (1955).

20) H.M. Davis, F.J.W. Garton, E.N. Jenkins, G.

W.C. Milner and H.I. Shalgosky, Proceedings of the Second United Nations Conference on the Peaceful Uses of Atomic Energy, Geneva 1958, P/79, Vol. 28, United Nations, New York (1958).

21) G.C. Barker, in "Proceedings of the Congress on Modern Analytical Chemistry in Industry," 1957, The Society for Analytical Chemistry, W. Heffer and Sons Ltd., Cambridge, p. 209.

22) G.C. Barker, Anal. Chim. Acta, 18, 118 (1958)

23) G. Mamantov, P. Papoff and P. Delahay, J. Am. Chem. Soc., 79, 4034 (1957) ; J.G. Nikelly and W.D. Cooke, Anal. Cnem., 29, 933 (1957); R.D. DeMars and I. Shain, ibid., 1825 (1957). 